\title{
Criteria Evaluation of the Results of the Implementation of the Business Process Automation System
}

\author{
Kateryna Holikova ${ }^{1 *}$, Svitlana Matsyura ${ }^{1}$, Viktoriia Radko $^{1}$, Nina Rudenko $^{2}$, and Daryna Zhukova ${ }^{2}$ \\ ${ }^{1}$ State University of Economics and Technology, Kryvyi Rih, Ukraine \\ ${ }^{2}$ Kryvyi Rih Technical College of the National Metallurgicall Academy of Ukraine, Krivyi Rih, Ukraine
}

\begin{abstract}
Approaches and methods of qualitative and quantitative analysis of business processes are analyzed, their advantages and disadvantages at application in an estimation of business processes of the enterprises and the organizations of various spheres of activity are defined. A method for determining the economic efficiency of the implementation of an automated design system, as well as indicators and criteria for assessing the economic efficiency of the implementation of an information system in the reengineering of business processes. The main examples of quantitative indicators are considered, in particular: process indicators, product (service) indicators and consumer and stakeholder satisfaction indicators. In the course of the research, recommendations were developed for the creation of a generalized system of indicators for assessing the business processes of enterprises and organizations, regardless of their field of activity.
\end{abstract}

\section{Introduction}

The use of the latest information technologies in business, economy, state administration and the other branches is the extremely necessary condition for the efficient development. In case, when this condition is not observed at the proper level, the development slowdown will take place and the possibility to get into the rating of the lagging behind and the inefficient ones will appear.

The EU pays a great attention to the development of the digital economy, considering that the economy level of the continent will depend on the fact, how efficiently the enterprises will use the digital technologies. The enterprises, being not integrated into the digital space, will not belong to the World market.

Thus, it's clear, that the realization of control is not possible without using the intellectual information technologies for the efficient organization of business. It's necessary to create the corresponding information system of the organization, which would be unified in all the structural subdivisions and would help to take the strategic and tactical managerial decisions efficiently. Taking into account, that the concept of the strategic development is left to be the dominating concept of the modern company's development, it's necessary to use the intellectual information technologies at all the phases and stages of the strategic decisions-taking at the formation of the company's information environment [1].

The modern information technologies are the computer processing of information, according to the previously processed algorithms, the storage of big amounts of information on different bearers, the analysis and the visualization of data and the information transmission at any distance within the utmost minimal time. The new era has come - the era of "Big Data" ("Big Data era") and "Data Mining" (the intellectual analysis of data).

That's why the information technologies are used in the economy and business for processing, sorting and aggregating of data, for the organization of the interaction between the process participants and the computing engineering, for the satisfaction of the information needs, for the operative connection at all the phases and stages of the organization's life cycle.

In general, in order to provide the competitive positions, the modern business solves the following three strategic tasks:

- it's necessary to establish the closest relations with suppliers and customers;

- to increase the level of the private operational efficiency;

- to increase the competitiveness of the production, being manufactured.

The fulfillment of all these tasks is not possible without the integration of information systems and technologies into the sphere of business.

We propose to examine the achievements of these three tasks through the prism of the organization's business-processes with the use of the definite information technologies (digital tools) (Table 1).

We also demonstrated the tasks, concerning the rational cooperation between the business-structures and the executive bodies, banks and others in this Table and presented the information technologies that had been already introduced into life at present and reflect the digital transformation of the corresponding interrelations between the corresponding subjects too.

* Corresponding author: golikova kp@kneu.dp.ua 
Considering that, you may come to the conclusion that all the subjects, using the corresponding information systems, had an opportunity to feel the considerable positive effect at the definite interaction.

Table 1. Organizational business process groups and digital technologies (systems, tools, programs) for their transformation [1].

\begin{tabular}{|c|c|}
\hline $\begin{array}{l}\text { Business process groups } \\
\text { organizations }\end{array}$ & $\begin{array}{l}\text { Digital tools (systems, } \\
\text { products, } \\
\text { software solutions) }\end{array}$ \\
\hline \multicolumn{2}{|c|}{$\begin{array}{l}\text { Task № } 1 \text {. Establishing a closer relationship with suppliers } \\
\text { and customers }\end{array}$} \\
\hline 1. Interaction with suppliers & $\begin{array}{l}\text { Systems SCM (Supply Chain } \\
\text { Management) }\end{array}$ \\
\hline $\begin{array}{l}\text { 2. Interaction with customers } \\
\text { (consumers) }\end{array}$ & $\begin{array}{l}\text { Systems CRM (Customer } \\
\text { Relationships Management) }\end{array}$ \\
\hline \multicolumn{2}{|c|}{ Task №2. Increase the level of own operational efficiency } \\
\hline 3. Resource management & $\begin{array}{l}\text { ERP (Enterprise Resources } \\
\text { Planning) }\end{array}$ \\
\hline $\begin{array}{l}4 . \quad \text { Business } \\
\text { management }\end{array}$ & $\begin{array}{l}\text { BPM- systems (Business } \\
\text { process management) }\end{array}$ \\
\hline $\begin{array}{l}\text { 5. Analytical management } \\
\text { component (data analysis) }\end{array}$ & $\begin{array}{l}\text { Technologies Big Data, Data } \\
\text { mining, OLAP-cube, } \\
\text { cloud computing, Google } \\
\text { Analytics }\end{array}$ \\
\hline $\begin{array}{l}\text { 6. Providing modern } \\
\text { employee technologies } \\
\text { companies to effectively } \\
\text { perform daily work }\end{array}$ & $\begin{array}{l}\text { Office } 365 \text {, Google doc, use } \\
\text { of CRM systems, dashboards } \\
\text { for key evaluation indicators }\end{array}$ \\
\hline \multicolumn{2}{|c|}{ Task №3. Increase the competitiveness of products } \\
\hline $\begin{array}{l}\text { 7. Product management } \\
\text { (control, storage and } \\
\text { providing the necessary } \\
\text { information) }\end{array}$ & $\begin{array}{l}\text { PLM (Product Lifecycle } \\
\text { Management) systems and } \\
\text { PDM (Product Data } \\
\text { Management), digital } \\
\text { sensors, GIS-technologies, } \\
\text { etc. }\end{array}$ \\
\hline 8. Marketing activities & $\begin{array}{l}\text { Digital internet } \\
\text { tools, Using } \\
\text { Analytics tools Google } \\
\text { Adwords; SEO and SMM }\end{array}$ \\
\hline \multicolumn{2}{|c|}{$\begin{array}{l}\text { Tasks for rational cooperation between business structures } \\
\text { and executive bodies, banks, etc. }\end{array}$} \\
\hline $\begin{array}{l}\text { When registering } \\
\text { liquidating a business }\end{array}$ & $\begin{array}{l}\text { Online service of the } \\
\text { Ministry of Justice of } \\
\text { Ukraine }\end{array}$ \\
\hline $\begin{array}{l}\text { State Tax Service, pension } \\
\text { fund, social services, bank }\end{array}$ & $\begin{array}{l}\text { Electronic reporting, } \\
\text { electronic signature }\end{array}$ \\
\hline Customs authorities & Single Window System \\
\hline
\end{tabular}

\section{Background}

The indicators of the business-processes are necessary to determine such targets, which are possible to be measured and controlled for the achievement of the defined purposes. The indicators of the businessprocesses are the indicator of the successful run of the processes and, on the contrary, indicate the presence of certain disadvantages. The indicators are the stimulus for the support of the existing level of standards, as minimum, and for the improvement in comparison with the competitors and the successful satisfaction of the constantly growing needs of the consumers, as maximum.

\subsection{Problem Positing}

As it's [2] mentioned in the work, the indicatiors' system of the process allows:

- estimate the state of the affairs at the initial stage (for the model "As is" ("As it is")), i.e. to define the starting point for the introduction of the improvement process;

- identify the processes, that require improvement;

- elaborate the forecast or the trend of the process development;

- compare the indicators' level of the researched enterprise with the analogous indicators of the competitors or with the average meanings in the corresponding branch of the economy;

- estimate the result of the already realized measures, concerning the improvement of processes;

- select the most corresponding tools for the further improvement.

The mostly-spread scientific approach to the classification and the differentiation of the estimation indicators of processes is the approach, offered by V.V. Repin and V.G. Yeliferov [3], based on the division of the processes analysis into the qualitative and the quantitative ones.

The generalization of these approaches allowed us determine the advantages and disadvantages in their use, presented in the Table 2 .

Table 2. Advantages and disadvantages of existing approaches and methods of business process analysis $[4,5,6]$

\begin{tabular}{|c|c|}
\hline $\begin{array}{c}\text { Type of } \\
\text { approaches and } \\
\text { methods to the } \\
\text { analysis of } \\
\text { business } \\
\text { processes } \\
\end{array}$ & Pros and cons \\
\hline \multicolumn{2}{|c|}{ Qualitative analysis of the business process } \\
\hline SWOT analysis & $\begin{array}{l}\text { Pros. Allows you to systematize } \\
\text { information about the invoices of } \\
\text { internal and external influence on } \\
\text { business processes. SWOT-analysis is } \\
\text { suitable for preliminary qualitative } \\
\text { evaluation of the business process, its } \\
\text { results can be useful for determining the } \\
\text { characteristics of the process and the } \\
\text { reasons for its low efficiency. } \\
\text { Cons. SWOT analysis is characterized } \\
\text { by a high level of subjectivity, its results } \\
\text { are a weak basis for management } \\
\text { decisions. }\end{array}$ \\
\hline $\begin{array}{l}\text { Analysis of } \\
\text { process problems }\end{array}$ & \multirow[b]{2}{*}{$\begin{array}{l}\text { Pros. Managers and direct participants } \\
\text { take part in the implementation of the } \\
\text { methods in the survey process } \\
\text { executors, which allows you to identify } \\
\text { problem areas of the process. Allows } \\
\text { you to determine the order of process } \\
\text { improvement. } \\
\text { Cons. The method allows to detect only } \\
\text { the presence of problems, but does not } \\
\text { allow to measure their depth. It is not } \\
\text { possible to assess the problems from a } \\
\text { financial point of view or from a point } \\
\text { of view view of quality indicators. }\end{array}$} \\
\hline $\begin{array}{l}\text { Ranking of } \\
\text { processes }\end{array}$ & \\
\hline $\begin{array}{lr}\begin{array}{l}\text { Analysis } \\
\text { inputs }\end{array} \\
\text { outputs }\end{array}$ & $\begin{array}{l}\text { Pros. These methods allow you to } \\
\text { determine the shortage or redundancy } \\
\text { inherent in the inputs, outputs, resources }\end{array}$ \\
\hline
\end{tabular}




\begin{tabular}{|c|c|}
\hline Function analysis & process. Their \\
\hline Resource analysis & structure business processes, to make \\
\hline Analysis of the & them more integral, to eliminate \\
\hline compliance with & the most poorly organized processes. \\
\hline $\begin{array}{l}\text { typical and / or } \\
\text { regulatory } \\
\text { requirements }\end{array}$ & $\begin{array}{l}\text { Cons. All of these types of analysis are } \\
\text { necessary for use, but none of them is } \\
\text { not a tool for fundamental reengineering } \\
\text { and implementation of deep changes in } \\
\text { business processes, increasing the } \\
\text { efficiency of business processes. }\end{array}$ \\
\hline \multicolumn{2}{|c|}{ Quantitative analysis of the business process } \\
\hline Simulation & $\begin{array}{l}\text { Pros. The method allows to consider a } \\
\text { large number of alternatives, to improve } \\
\text { quality management decisions and more } \\
\text { accurately predict their consequences. } \\
\text { Allows you to find what you need } \\
\text { solution in case of impossibility of } \\
\text { conducting an experiment in real life. } \\
\text { Cons. The complexity and high cost of } \\
\text { using the method. }\end{array}$ \\
\hline $\mathrm{ABC}$ analysis & $\begin{array}{l}\text { Pros. Clarity of the analyzed indicators, } \\
\text { accuracy of the calculated parameters, } \\
\text { possibility of automation of the analysis. } \\
\text { Cons. Requires restructuring of the cost } \\
\text { accounting system in the enterprise, } \\
\text { because on most companies do not have } \\
\text { a system of process accounting of } \\
\text { process costs. }\end{array}$ \\
\hline $\begin{array}{l}\text { Analysis of } \\
\text { process, product } \\
\text { and customer } \\
\text { satisfaction } \\
\text { indicators }\end{array}$ & $\begin{array}{l}\text { Pros. Indicators characterize the main } \\
\text { components of the business process } \\
\text { from different points vision (financial, } \\
\text { technical, etc.). Indicators carry } \\
\text { objective information in numerical } \\
\text { terms, outline the "problem areas" of the } \\
\text { studied object. } \\
\text { Cons. Process, product and customer } \\
\text { satisfaction indicators are separated } \\
\text { characteristics, on their basis it is } \\
\text { difficult to determine the assessment of } \\
\text { the effectiveness of the study object as a } \\
\text { whole. }\end{array}$ \\
\hline
\end{tabular}

The conducted generalizations of the existing approaches to the estimation of business-processes testify to the fact that the qualitative analysis gives the possibility to get information of the run's peculiarities of processes, the presence of the problem sections, the "narrow places", the excessive or the missing functions of the processes. The qualitative analysis is the distinctly structurized characteristic feature of the business-process, which is the very important background for the further realization of the quantitative analysis.

The quantitative analysis, in its turn, allows get the numerical values that characterize the run of the business-process, define its state from the viewpoint of the technical requirements, the quality indicators. The quantitative analysis gives the possibility to measure the degree of the business-process efficiency, to calculate the profitability, to define the time characteristic features of the business-process. It's possible to set the normatives, to correct the strategic purposes, to foresee the further development of the organization, according to the results of the quantitative analysis [7].
As far as the indicators, by which the quantitative analysis of the process operates, are concerned, then, there are three groups of indicators here:

- the indicators of the business-process - the numerical values, characterizing the process run and the financial, the time, the resource and the human losses;

- the indicators of the product (service) - the numerical values, characterizing the product (service) as the result of the process realization. For example, the absolute scope of services, the scope of services in relation to the ordered or the needed amount, the number of mistakes or breakdowns at the presentation of service, the nomenclature of the presented services in relation to the necessary services;

- the satisfaction indicators of the process clients the numerical values, characterizing the consumers' satisfaction degree with the process result. It's important to distinguish the satisfaction of the internal consumer or the external one with the process result and the satisfaction of the final consumer with the production or the service [3].

The indicators, characterizing the business-process, may be presented in the following way (Table 3 ).

Table 3. Types of business process indicators.

\begin{tabular}{|l|l|}
\hline \multicolumn{1}{|c|}{$\begin{array}{c}\text { See } \\
\text { indicators }\end{array}$} & \multicolumn{1}{c|}{ Examples of indicators by type } \\
\hline $\begin{array}{l}\text { Financial } \\
\text { Indicators }\end{array}$ & $\begin{array}{l}\text { The cost of the business process; } \\
\text { Costs of raw materials and supplies; } \\
\text { Labor costs of performers; } \\
\text { Amortization; } \\
\text { Heat and energy costs; } \\
\text { Communication and acquisition costs } \\
\text { information; }\end{array}$ \\
\hline $\begin{array}{l}\text { Technical } \\
\text { Indicators }\end{array}$ & $\begin{array}{l}\text { The number of business process features } \\
\text { that performed in the workplace; } \\
\text { Number of staff, including } \\
\text { managers and specialists; }\end{array}$ \\
\hline Temporary & $\begin{array}{l}\text { The average process execution time in } \\
\text { in general; } \\
\text { Average downtime; } \\
\text { The average execution time of } \\
\text { individual business process functions; }\end{array}$ \\
\hline
\end{tabular}

O. Kochnyev and the iTeam [8, 9] company professionals offer the classification of the businessprojects indicators, in the frames of the quantitative approach, with the separation of the four main groups of indicators: effectiveness, efficiency, productiveness, quality, - and the three auxiliary groups of indicators: activity of performers, losses of resources, profit (Table 4).

The evaluation's express-method of businessprocesses was offered by K.K. Chuprov in the work [10] in 2005. The evaluation system's following components of the business-projects' control efficiency are determined, according to this method: the efficiency indicators of the separate processes; the qualitative indicators of the enterprise's production; the indicators of the clients' satisfaction with the results of the enterprise's activity; the microeconomic and the financial indicators of the activity. The express-method of the business-processes' evaluation of K.K. Chuprov is founded on the principles and methods of the 
structural modelling, the object-oriented modelling, the analysis of cost, according to the processes, and the analysis of the key indicators.

Table 4. The main indicators of the business process (according to O. Kochnev).

\begin{tabular}{|c|c|}
\hline $\begin{array}{c}\text { The main } \\
\text { groups of } \\
\text { business process } \\
\text { indicators and } \\
\text { their essence } \\
\end{array}$ & Examples of indicators \\
\hline $\begin{array}{l}\text { Effectiveness - } \\
\text { the indicator is a } \\
\text { measure of the } \\
\text { result useful for } \\
\text { the client process }\end{array}$ & $\begin{array}{l}\text { Number of clients who applied; } \\
\text { Sales volume; } \\
\text { Number of concluded agreements; } \\
\text { Production volume; } \\
\text { Delivery time }\end{array}$ \\
\hline $\begin{array}{l}\text { Efficiency is an } \\
\text { indicator } \\
\text { characterizes the } \\
\text { ratio of the } \\
\text { achieved result } \\
\text { and used } \\
\text { resources }\end{array}$ & $\begin{array}{l}\text { The cost of attracting a client; } \\
\text { Sales conversion; } \\
\text { Average check; } \\
\text { Cost of production; } \\
\text { Shipping cost }\end{array}$ \\
\hline $\begin{array}{l}\text { Productivity - an } \\
\text { indicator that } \\
\text { characterizes the } \\
\text { ratio of } \\
\text { achievements } \\
\text { result and human } \\
\text { resources used }\end{array}$ & $\begin{array}{l}\text { Sales per person employee; } \\
\text { Number of customers served by one } \\
\text { employee; } \\
\text { Production volume per employee; } \\
\text { Revenue per employee; } \\
\text { Profit per employee }\end{array}$ \\
\hline $\begin{array}{l}\text { Quality indicator } \\
-\quad \text { reflects the } \\
\text { degree of } \\
\text { customer } \\
\text { satisfaction of the } \\
\text { business process } \\
\text { with the result }\end{array}$ & $\begin{array}{l}\text { Product quality indicators (services): } \\
\text { the degree of defect of the process } \\
\text { products; } \\
\text { number of defects, incomplete orders; } \\
\text { marriage elimination costs; } \\
\text { Service quality indicators: } \\
\text { the number of returns and complaints on } \\
\text { the products of the process; } \\
\text { number of complaints and reclamations } \\
\text { on the quality of service that received } \\
\text { from customers; } \\
\text { the number of emergency situations to } \\
\text { be resolved the participation of the } \\
\text { higher was required leadership }\end{array}$ \\
\hline
\end{tabular}

The work's author [10] suggests to use the methods of the functional modelling IDEF and DFD or the modelling methods of the integrated information systems ARIS, ORACLE, SAP/R3, BAAN for the construction of the processes' models. It's offered to calculate such indicators of the business-processes' efficiency on the basis of the constructed models of the processes as complexity, processability, controllability, resource-capacitance, regulatedness. The normative meanings of these indicators are calculated by the author [10].

To calculate these indicators, quantitative values of such basic parameters as:

- the number of levels of the business process system $(\mathrm{Pl})$ should be identified;

- number of copies of business processes (Pc);

- the number of "gaps" in the process instances $(\mathrm{Pg})$;

- number of business process classes (Pcl);

- number of business process owners (PO);

- the number of resources used to perform the process $(\mathrm{R})$;
- the number of outputs in copies of business processes (Pout);

- number of regulatory documents (Preg).

The principle of calculating indicators according to the express method of assessing business processes K.K. Chuprov is presented in table. 5 .

Table 5. Calculation of indicators in accordance with the express method of assessing business processes K.K. Chuprov.

\begin{tabular}{|c|c|c|}
\hline Indicator & $\begin{array}{c}\text { Calculation } \\
\text { formula }\end{array}$ & $\begin{array}{c}\text { Normative } \\
\text { value }\end{array}$ \\
\hline $\begin{array}{l}\text { The complexity index is the } \\
\text { ratio of the number of levels of } \\
\text { decomposition process models } \\
\text { to the total amount of selected } \\
\text { processes, determines how } \\
\text { complex is the hierarchical } \\
\text { structure of business processes }\end{array}$ & $\begin{array}{c}\text { Icomp }=\mathrm{Pl} \\
/ \mathrm{Pc}\end{array}$ & $\underset{0,66}{\text { Icomp }} \leq$ \\
\hline $\begin{array}{l}\text { Process index - the ratio of the } \\
\text { number of "gaps" (lack of } \\
\text { causal relationship between the } \\
\text { subprocesses of the process that } \\
\text { considered) in business } \\
\text { processes to the sum of the } \\
\text { classes of the business process, } \\
\text { characterizes the integrity of } \\
\text { the process, which can be } \\
\text { defined as problematic, or as a } \\
\text { process }\end{array}$ & $\begin{array}{c}\mathrm{Ipr}=\mathrm{Pg} / \\
\mathrm{Pcl}\end{array}$ & Ipr $<1$ \\
\hline $\begin{array}{l}\text { Controllability indicator - the } \\
\text { ratio of the number of process } \\
\text { owners to the number of } \\
\text { business process classes, } \\
\text { characterizes the efficiency } \\
\text { managing the owners of } \\
\text { business processes that belong } \\
\text { to them }\end{array}$ & $\begin{array}{c}\text { Icont }=\mathrm{PO} / \\
\mathrm{Pcl}\end{array}$ & Icont $<1$ \\
\hline $\begin{array}{l}\text { Resource intensity - the ratio of } \\
\text { the number of resources used to } \\
\text { "Outputs", the results of the } \\
\text { business process, demonstrates } \\
\text { efficiency use of resources in } \\
\text { the implementation of a } \\
\text { particular business process }\end{array}$ & $\begin{array}{c}\text { Ires }=\mathrm{R} / \\
\text { Pout }\end{array}$ & Ires $<1$ \\
\hline $\begin{array}{l}\text { Regulability - the ratio of the } \\
\text { amount of regulatory } \\
\text { documentation } \\
\text { to the number of classes of } \\
\text { business processes, determines } \\
\text { the level of regulation current } \\
\text { processes }\end{array}$ & $\begin{array}{c}\text { Ireg }=\text { Preg } \\
/ \text { Pcl }\end{array}$ & Ireg $\geq 1$ \\
\hline
\end{tabular}

After calculating the five performance indicators, an integrated indicator is calculated. If its regulatory value is within $1 \leq \Sigma \mathrm{K} 2$, the business process is considered inefficient and in need of change. S.M. Kovalev and V.M. Kovalev [11] in 2005 proposed a method of analyzing business processes by critical success factors. The authors suggest such indicators for the selection of the prior business-processes as the importance of the business-process, the problemsness of the business-process and the possibility and the cost of the business-process changes' realization. It's suggested to evaluate the Critical Factors of Success (CFS), flowing out of the company's mission after its decomposition into the strategic purposes (targets), 
according to these criteria. Basing on the Pareto Rule, S.M. Kovalyov and V.M. Kovalyov offer them from the plural number of the strategic purposes.

The criterion of the business-process importance characterizes the contribution's weight of the definite business-process into the achievement of the company's strategic purposes. It's offered to define the importance of the business-process with the help of the matrix of the CFS comparison with the businessprocesses. The quantitative evaluation of the businessprocesses' importance is defined as the sum of the CFS, affecting the business-process and lying in the range from 1 to 8 , or each CFS is given the weight coefficient, which characterizes its importance, and the evaluation scale of the business-process' correspondence, according to the criterion of importance, is elaborated. In order to estimate the problemness of the business-processes, it's worth to define the main problems of the business-processes previously and to evaluate the force of these problems, according to the scale from 1 to 5 , to compare the results with the problemness scale of the businessprocesses, offered by the authors, by having estimated them from 1 to 5 , or to elaborate the private scale of the problemness evaluation, considering the specific character of the organization's activity. The final coefficient of problemness is calculated as the sum of the problems' forces and the problemness degree of the business-process. The following step, offered by the authors, is to elaborate the matrix of the businessprocesses' ranging with the scales of importance and problemness, in order to define the priority of the business-processes. Those business-processes will be the most prior ones, which are characterized by the greatest level of importance and problemness. The authors of the methods propose to evaluate the possibility degree of changes realization in the frames of the three groups of the barriers, being able to prevent from changes introduction, they are - finances, the personnel and the legislation. It's necessary to estimate the value of the barriers, according to the scale from 1 to 5 , after the definition of the main barriers in every business-process. The summary value of all the barriers is calculated after that, which will be the searching coefficient of the changes realization's probability. The priority of the business-processes is finally defined as the sum of importance, problemness and the possibility degree of changes realization. The most prior is the process, for which the sum of the indicators is the biggest one. The re-engineering of the processes, which operation is unsatisfactory at the present moment, is realized in the first turn, the attention is paid after them to the processes, having the average influence on the operation of the enterprise; the attention is paid to the processes, having the insufficient influence or working well enough, in the final turn.

It's reasonably to separate several methods of the results' efficiency evaluation of the information systems' introduction among the researched methodical instruments at the re-engineering of the business-processes, where the subjectivism element of the expert evaluation may be essentially reduced. Let's mark the following ones among them:

- the analysis of the efficiency key indicators and the evaluation of the effectiveness balanced indicators;

- the fuctional-cost analysis;

- the analysis of the investment's repayment;

- the evaluation of the possession's aggregate cost. You may not find today many domestic companies, being able to introduce the integrated system of their activity's evaluation, based on the use of the presented models. It's worth recognizing, that the abovementioned models of the financial result evaluation are not widely-known till the present time not only in Ukraine, but in the developed industrial countries, having essentially more experience in the use of the information systems at the realization of re-engineering [12].

Let's investigate the types of the economic efficiency that may be estimated at the information system's introduction of the re-engineering measures' monitoring at the industrial enterprise. It's necessary to notice that there are the absolute and the relative (comparative) economic efficiencies. As the scientisteconomist L. Vodachek indicates, the analysis of the already selected (or even the realized) variant of the information system's introduction is conducted without any accounting of the possible alternatives in the first case. In the other case, the alternative strategies of the system's introduction are compared with each other from the position of the economic efficiency. You may also calculate the specific indicators of the efficiency (per one hrivnya of the contributed costs, per one employee and so on) [13].

\subsection{Presentation of Materials and Results}

According to the economic efficiency evaluation methods of business-processes re-engineering, analyzed by the author of the research, you should ascertain the absence of the united approach to the solvation of this problem.

Let's examine the calculation of the absolute efficiency of the information system's introduction at the realization of business-processes re-engineering. From the positions of the user (the final consumer) of the information system, the absolute efficiency of the introduction is defined as the relation of the difference between the obtained results (or the evaluation of these results in future) and the costs for the introduction to the corresponding costs for the introduction of the information system. If the enterprise has not been automated in general before the realization of the evaluation operations, it's enough to compare the activity results without any introduction before the reengineering measures $-R_{1}$ at the corresponding zero costs $\left(S_{1}=0\right)$ - with the results after the introduction at the realization of re-engineering $-R_{2}$ at the corresponding costs $\mathrm{S}_{2}$. The simplified indicator of the efficiency (E) is calculated, according to the formula [14]:

$$
E=\frac{\left(R_{2}-R_{1}-S_{2}\right)}{S_{2}} \cdot 100 \%
$$


At this, the difference $\left(R_{2}-R_{1}\right)$ characterizes the obtained effect from the main activity of the enterprise after the project realization of the information system's introduction at business-processes re-engineering.

The value of the aggregate costs for businessprocesses automation at their further re-projection and the formation of the new business-process, as a rule, is composed of the following:

- the cost of the used computers;

- the cost of printers, the system equipment and the other devices;

- the cost of the program products or the licences for their use;

- the costs for the installation, introduction, adaptation, studying and the accompaniment of the program complexes;

- the evaluation of losses, due to the change of the control structures, the personnel re-organization and so on;

- all the current costs (for the electrical energy, premises, communication and so on).

In case, when the introduced information system of business-processes automation has been already at the enterprise, it's necessary to take into account the current costs for its maintenance and to compare the effects at the basic and the actual variants of the system's introduction. Due to that, we offer to define the economic efficiency from the introduction of the automated projection (designing) system at businessprocesses re-engineering in the following way:

$$
E=\frac{\left(R_{2}-R_{1}\right)-\left(S_{2}-S_{1}\right)}{S_{2}-S_{1}} \cdot 100 \%
$$

where $\left(R_{2}-R_{1}\right),\left(S_{2}-S_{1}\right)$ - is the difference of the results $\left(R_{2}-R_{1}\right)$ and $\left(S_{2}-S_{1}\right)$, the difference of the costs at the new and the basic variants of the information system of the enterprise's businessprocesses automation, being subjected to re-projection. E characterizes the CFS efficiency coefficient, on which ground the criterial base of the economic efficiency evaluation of the information system's introduction is offered.

It's completely clear that if $\mathrm{E}>0$, then, the system's introduction was held effectively. How much effectively it was really done is shown by the relative indicator of the efficiency per one hrivnya of the aggregate costs, which is reflected by the quantity of the effect's hrivnyas, coming per one hrivnya of the realized costs (including the time factor). The use of the CFS relative indicator gives the opportunity to define the optimal variant of the automated projection (designing) system's introduction at re-engineering of business-processes at different budgets of the projects. In order to realize the expert evaluation of the measures, concerning the business-processes automation, the expert groups need the corresponding criterial base at the definition of the projects' economic efficiency. The indicators and the criteria of the information system introduction's economic efficiency at re-engineering of business-processes are offered in the Table 6.
Let's mention that the ranges of the economic efficiency indicators of the automated projection (designing) system's introduction at re-engineerng of business-processes are obtained, according to the results of the bench-marking research of the transformation/restructuring projects of the Ukrainian industrial enterprises of the machine-building, light, processing, coal and the oil-gas industries of Ukraine on the basis of calculation of the expected results from the introduction of these projects [14].

Basing on the presented Table 1, we separated the four meanings' areas of the specific efficiency coefficient of the automated projection system's introduction at re-engineering, forming the strong, the sufficient, the weak and the insufficient economic efficiency levels of business-processes automation at the realization of their further re-projection. It allows increase the quality of the realized evaluation and establish the more real economic efficiency's level of the measures, concerning the introduction of information systems $[15,16]$.

Let's indicate in total, that the presented criterial base may be also used at the definition of the economic effects from the synergetic influences on the economic potential of the industrial enterprise.

Table 6. Indicators and criteria for assessing the costeffectiveness of information system implementation in business process reengineering.

\begin{tabular}{|c|c|c|}
\hline Indicator & Value & Conclusion \\
\hline \multirow{4}{*}{$\begin{array}{c}\text { Index } \\
\text { efficiency }\end{array}$} & Ief $>2$ & $\begin{array}{l}\text { We can talk about real success in } \\
\text { business by increasing } \\
\text { controllability of the enterprise on } \\
\text { the basis of new information } \\
\text { technologies, and, consequently, } \\
\text { conducting effective reengineering } \\
\text { of business processes }\end{array}$ \\
\hline & $\begin{array}{l}1<\text { Ief }< \\
2\end{array}$ & $\begin{array}{l}\text { This range of values of the specific } \\
\text { coefficient of efficiency indicates } \\
\text { sufficient efficiency of the project } \\
\text { results during reengineering } \\
\text { business processes and eliminate } \\
\text { bottlenecks in business processes }\end{array}$ \\
\hline & $0 \leq \operatorname{Ief}<1$ & $\begin{array}{l}\text { This range of coefficient values } \\
\text { indicates a weak economic } \\
\text { efficiency and about possible } \\
\text { negative tendencies in introduction } \\
\text { of IS at conducting reengineering. } \\
\text { It is advisable to talk about the } \\
\text { impact internal and external } \\
\text { factors that interfere with normal } \\
\text { conducting reengineering of } \\
\text { business processes, in particular } \\
\text { about error set goals and objectives } \\
\text { of business process reengineering, } \\
\text { inefficient strategic planning, } \\
\text { incomplete compliance with the } \\
\text { implemented IP reengineering and } \\
\text { technological processes at the } \\
\text { enterprise, etc. }\end{array}$ \\
\hline & Ief $<0$ & $\begin{array}{l}\text { The reengineering project is } \\
\text { unprofitable due to excess costs } \\
\text { implementation of an information } \\
\text { system over the expected results }\end{array}$ \\
\hline
\end{tabular}




\section{Conclusions}

The indicators of business-processes are the irreplaceable tool to control the achievement of purposes, to compare with the normatives, the standards and the achievements of the competitors, to control the satisfaction of the consumers. The use of the qualitatively elaborated system of the businessprocesses' indicators is the guarantee of the successful introduction of the process approach to the activity of any enterprise or organization. The system of indicators will allow define the efficiency or inefficiency of the processes' run, it will point out the low effectiveness and promote for the quick solvation of the problem questions in the very that part of the business-process, where it is necessary.

The modern researchers separate the qualitative and the quantitative analysis of business-processes. The use of the qualitative analysis methods of businessprocesses gives the possibility to structure the processes, to avoid the "narrow places", to define the improvement regularity of the processes. However, the existing methods of the qualitative analysis are intrinsic in the significant subjectivism and the definite "erosion" of the obtained information, not giving any opportunity to take the strategic managerial decisions on the basis of the results, received at the use of the qualitative analysis.

The methods of the quantitative analysis, in contrast to the qualitative one, operate by the facts, the numerical values, allow avoid the subjective evaluations and the mistaken interpretations, received, due to the insufficient formalization of the conclusions. At this, we grounded a series of both advantages and disadvantages in the run of the conducted investigations for the comprehensive use of these methods in the evaluation of business-processes of enterprises and organizations. Besides, the absence of the experience to calculate the costs in the processes stands as an obstacle on the use of such quantitative analysis method as the ABC method, but the introduction of the balanced indicators' system requires the essential enlargement of the costs for the marketing researches and the internal audit.

The express-method of business-processes evaluation, offered by K.K. Chuprov, is worth being referred to the advantages, due to the possibility to realize the evaluation of business-processes quickly enough, by avoiding the complex calculations and the subjective qualitative methods. However, the expressmethod of K.K. Chuprov may be used only on conditions of the previous description of the businessprocesses with the use of the modelling methods IDEF, DFD, ARIS. Besides, the use of the presented methods does not allow realize the deep evaluation, which may become an obstacle to the demonstration of the unobvious problems of the process.

The methods of the business-processes' analysis, according to the Critical Factors of Success, offered by S.M. Kovalyov and V.M. Kovalyov, are simple enough and understandable from the viewpoint of selection of the prior business-processes, but they require the closer definition of the notions: the force of the problem, the problemness of the business-process or it's necessary to make these notions more exact and to elaborate the criteria of their evaluation for each enterprise individually. Besides, it's necessary to define the coordination degree of the experts, while calculating the coefficient of concordation - for the methods, that foresee the application's possibility of the expert evaluations' method.

The key aspects of the economic efficiency evaluation of business-processes re-engineering at the industrial enterprise are examined. The economic efficiency increase ways of the enterprise's functioning at the realization of re-engineering are separated. The calculation of the absolute efficiency of the information system's introduction at the re-engineering realization of business-processes is examined. The method of the economic efficiency definition from the introduction of the automated projection system and also the indicators and the criteria of the economic efficiency evaluation of the information system's introduction at re-engineering of business-processes are offered.

\section{References}

1. I. Strutynska Information technologies of business organization - imperative of innovative development of business structures, Halytskyi ekonomichnyi visnyk, 2 (2018), pp. 40-49 available at: http://nbuv.gov.ua/UJRN/gev_2018_2_6

2. B. Andersen Byznes-protsessy. Ynstrumenty sovershenstvovanyia, Business Process Improvement Toolbox: Translated by Arynycheva S.V., RYA «Standarty y kachestvo», Moscow, Russia (2003)

3. V. Repyn, V. Yeliferov Protsessnyj podkhod k upravlenyiu. Modelyrovanye byznesprotsessov [The process approach. Business process modeling], RYA «Standarty y kachestvo», Moscow, Russia (2004)

4. B. Zuhaira, N. Ahmad, Business process modeling, implementation, analysis, and management: the case of business process management tools, Business Process Management Journal, Vol. 27 No. 1 (2020), pp. 145-183. https://doi.org/10.1108/BPMJ-06-2018-0168

5. A. Gunasekaran, B. Kobu Modelling and analysis of business process reengineering International Journal of Production Research Vol. 40 (2010), pp. 2521-2546. https://doi.org/10.1080/00207540210132733

6. R. Parthasarthy, S. Prakash Sethi The Impact of Flexible Automation on Business Strategy and Organizational Structure, Academy of Management ReviewVol. 17, No. 1 (1992) https://doi.org/10.5465/amr.1992.4279572

7. V. Tigareva, I. Stankevich Analysis of existing approaches and methods of evaluation of business processes of enterprises and organizations, Bulletin KrNU of Mykhailo Ostrohradskyi (98) 
(2016), pp. 113-122 available at: http://visnikkrnu.kdu.edu.ua/statti/2016_3_113-32016-2.pdf.

8. V. Sytnyk Imitatsijne modeliuvannia, Imitation modeling, KNEU, Kyiv, Ukraine (1999)

9. S. Bratushka Imitation modeling as a tool for exploring complex economic systems, Transactions of Ukrainian Academy of Banking, no. 2 (2009), pp. 113-128.

10. K. Chuprov The Express-method of diagnostics of the business processes of the company, Konsul'tant dyrektora, no. 20 (2005), available at: cfin.ru/management/controlling/fsa/express.shtml

11. S. Kovalev, V. Kovalev Selection the business processes for optimization, Konsul'tant dyrektora, no. 5 (2005), available at: betec.ru/index.php?id $=6 \&$ sid $=39$

12. L. Taranyuk Estimation of economic efficiency of carrying out reengineering of business processes at the enterprise Bulletin of Sumy State University. Economics series 2 (2009) pp. 168-178

13. L. Vodachek Strategy of innovation management at the enterprise: monograph, Ekonomika, 1989. pp. $205-210$

14. K. Mironenko Estimation of economic efficiency of reengineering of business processes at the industrial enterprise, 5 (2) (2016), pp. 51-56 available at: http://nbuv.gov.ua/jpdf/ecfipr_2016_5\%282\%29_14.pdf

15. M. Alles, G. Brennan, A._Kogan, M. Vasarhelyi Continuous Monitoring of Business Process Controls: A Pilot Implementation of a Continuous Auditing System at Siemens, Chan, D.Y., Chiu, V. and Vasarhelyi, M.A. (Ed.) Continuous Auditing (Rutgers Studies in Accounting Analytics), Emerald Publishing Limited, (2018), pp. 219-246. https://doi.org/10.1108/978-1-78743413-420181010

16. A. Babkin, S. Kuzmina, A. Oplesnina, A. Kozlov Selection of Tools of Automation of Business Processes of a Manufacturing Enterprise, 2019 International Conference «Quality Management, Transport and Information Security, Information Technologies» (IT\&QM\&IS) (23-27 Sept. 2019) https://doi.org/10.1109/ITQMIS.2019.8928302 